\title{
APPLICATION OF RULE OF LAW BY JURISDICTION SYSTEM ON ILLEGAL LOGGING CASE IN INDONESIA 2002-2008
}

\author{
Yudistira Hendra Permana ${ }^{2}$ \\ Universitas Gadjah Mada \\ (yudistira_hp@yahoo.com)
}

\begin{abstract}
The aim of this research is to analyze behavior of Supreme Court's judge on detention period sentence for illegal logging defendants in Indonesia from year 2002 through 2008. The first analysis is censored normal regression method using detention period indictment by prosecutor, detention period sentence by district court, defendant's gender, appeal effort, defendant's age, and defendant's job variables. Those variables are used to analyze how each variable affect on Supreme Court's verdict on detention period sentence for illegal logging defendants in Indonesia. Second analysis is descriptive statistic involves three levels of jurisdiction's considerations (prosecutor, district court, and Supreme Court) on determining detention period sentence for illegal logging defendants in Indonesia and suitability those three levels of jurisdiction to law. Research's result shows that detention period indictment by prosecutor, detention period sentence by district court, and defendant's age significantly affect on Supreme Court's verdict on detention period sentence for illegal logging defendants in Indonesia. But, on the other hand there is unsuitable verdict made by those three levels of jurisdiction to law.
\end{abstract}

Keywords: court's verdict, illegal logging, censored normal regression

1 This article has been awarded as the $1^{\text {st }}$ best paper of JIEB's Best Paper Awards 2010.

2 I am grateful to Rimawan Pradiptyo for his excellent guidance. 